\title{
What drives compliance? The effect of deterrence and shame emotions on young drivers' compliance with road laws
}

Siobhan Allen*

School of Criminology and Criminal Justice and Griffith Criminology Institute, Griffith

University, Brisbane Australia

School of Criminology and Criminal Justice, Room 3.09, Social Sciences building (M10),

Griffith University, 176 Messines Ridge Road, Mt Gravatt Qld, Australia 4122

$\underline{\text { Ph: }+61737351146}$

siobhan.allen@griffithuni.edu.au

Siobhan Allen is a Doctoral Candidate with the School of Criminology and Criminal Justice at Griffith University. Her research interests include youth offending, compliance, graduated driver licensing, procedural justice, and policing.

Kristina Murphy

School of Criminology and Criminal Justice and Griffith Criminology Institute, Griffith University, Brisbane Australia

\section{t.murphy@griffith.edu.au}

Kristina Murphy is an Associate Professor and Deputy Head of School (Research) in the School of Criminology and Criminal Justice at Griffith University. She is also Deputy Director of the Griffith Criminology Institute. Her primary research interests include procedural justice, policing, and legitimacy.

Lyndel Bates

School of Criminology and Criminal Justice and Griffith Criminology Institute, Griffith University, Brisbane Australia

Centre for Accident Research and Road Safety Queensland (CARRS-Q), Queensland University of Technology, Brisbane, Australia

l.bates@griffith.edu.au 
Dr Lyndel Bates is a Lecturer in the School of Criminology and Criminal Justice and a member of the Griffith Criminology Institute at Griffith University. Her research interests include road policing, the intersection of health and criminology, graduated driver licensing and the translation of research into policy.

*Corresponding Author 


\title{
What drives compliance? The effect of deterrence and shame emotions on young drivers' compliance with road laws
}

\begin{abstract}
Graduated driver licensing (GDL) is designed to reduce young driver injuries and fatalities on the road. While GDL systems impose additional restrictions on new drivers to reduce this crash risk, compliance with these restrictions and other licensing requirements can be low for young drivers. This research examines the influence of informal and formal deterrence measures on the compliance of provisionally licensed drivers, and the role that shame plays in mediating these relationships. The key independent variables measured were informal deterrence imparted by parents, formal deterrence imparted by police, and shame-related emotion, while compliance with road laws was the dependent variable. Using survey data from 151 young provisionally licensed drivers from Australia, the results indicate that informal deterrence, but not formal deterrence, is related to young drivers' compliance with road rules. Further, the effect of informal deterrence on compliance behaviour was mediated by young drivers' feelings of shame over wrong-doing. These findings suggest that internal psychological mechanisms need to be examined in addition to deterrence processes to understand young drivers' compliance behaviour. Importantly, this study has key policy implications including the utilisation of third-party policing practices such as the inclusion of parents in monitoring young drivers' behaviour on the road.
\end{abstract}

Keywords: deterrence; shame; policing; compliance.

\section{Introduction}

Young, newly licensed drivers are the group of drivers with the highest crash risk (Bates et al., 2014b). In fact, the number one cause of death for young people aged from 15 to 29 years old is road traffic injuries (World Health Organisation, 2007, World Health Organisation, 2009). Research around the world consistently demonstrates that young drivers are overrepresented in serious and fatal crashes (Whelan et al., 2009), with one review 
reporting the elevated crash rate for young drivers to be 5 to 10 times higher than for middleaged drivers (Elvik, 2010). A number of influences have been identified that contribute to the crash risk of young novice drivers (Bates et al., 2014b). These include inexperience (Mayhew et al., 2003, Bates et al., 2014b), age (McCartt et al., 2009, Bates et al., 2014b), and gender (with boys more likely to be involved in crashes; Ginsburg et al., 2008, Bates et al., 2014b).

Graduated driver licensing (GDL) is a countermeasure that has been effective in reducing young driver crashes (Shope, 2007, Neyens et al., 2008, Pressley et al., 2009, Masten and Foss, 2010, McCartt et al., 2010, Lyon et al., 2012, Williams et al., 2012, Bates et al., 2014a). GDL involves more stringent restrictions placed on drivers when they first obtain their drivers' licence (Williams et al., 2012). Restrictions can include limiting the number of passengers a novice driver has in the car or limiting driving past a certain time at night. These restrictions are then relaxed over time as the young driver gains more experience on the road (Williams et al., 2012).

Research suggests that there are a number of jurisdictions that implement GDL policies for novice drivers (Foss et al., 2001, Begg and Stephenson, 2003, Bates et al., 2014a), including Canada, New Zealand, the United States of America, and Australia (Shope, 2007, Williams et al., 2012). The GDL system in North Carolina, for example, requires young drivers to have a supervisor present in the vehicle for the first 12 months of driving (Foss et al., 2001). This restriction has been found to reduce crashes among 16 year old drivers by up to $43 \%$ after three years (Foss et al., 2001). In fact, GDL schemes have consistently demonstrated successful reductions in crash statistics among novice drivers (Hedlund, 2007, Shope, 2007). Shope (2007), for example, reviewed 21 studies that had evaluated GDL systems throughout the United States and Canada. This meta-analysis indicated that GDL systems consistently showed positive results of varying degrees in 
reducing crashes, with the author stating that overall the crash risks of young drivers under a GDL system had reduced roughly 20 to 40\% (Shope, 2007).

Of course, the positive influence of GDL is only effective if those who must abide by the system are compliant with its restrictions and the road rules more generally. In the current study, we examine the road compliance behaviour of young drivers who hold a provisional driver's license; those at most risk of injury and death while driving. We are interested in testing how both formal and informal mechanisms of social control can exert an influence on young drivers’ compliance with road rules and their GDL restrictions.

\section{Compliance, Enforcement and Deterrence of Young Drivers' Compliance Behaviour}

As noted above, research has shown that GDL systems appear to reduce the crash risk of young, novice drivers. With the introduction of GDL schemes, that require compliance with a greater number of laws, a few studies have attempted to evaluate whether they have an effect on young drivers' compliance behaviour on the road. An Australian study by ScottParker et al. (2012), for example, evaluated the compliance of learner and provisionally licensed drivers regarding GDL restrictions and general road laws. Their study used selfreport survey data and revealed that drivers were less compliant as they progressed through the GDL system. Those less experienced drivers on Provisional 1 licenses tended to be more compliant than Provisional 2 licensed drivers (Scott-Parker et al., 2012). Compliance has also been found to vary across the different restrictions present within a GDL system. For example, novice drivers are more likely to comply with night-time driving restrictions than they are with restrictions that limit the number of peer-passengers they have in the car (Hedlund, 2007, Bates et al., 2014a).

Interestingly, family and social environments have been found to impact on young driver behaviour, particularly the role of parents in teaching novice drivers how to drive. Taubman - Ben-Ari and Katz - Ben-Ami’s (2012) research revealed that those novice drivers 
who perceived that their parents were good role models, who provided encouraging feedback, communicated effectively, monitored their driving, obeyed authoritative figures, and had clear limits on breaking traffic laws, were themselves less likely to engage in reckless driving (this included breaking road rules). Such research reveals that parents may have a considerable effect on young driver compliance more generally.

While a number of measures have been introduced to place restrictions on novice drivers through GDL systems, enforcing compliance with these restrictions and sanctioning young drivers for non-compliance is actually quite difficult, particularly if police are unable to identify young novice drivers on the road Hedlund (2007). It is for this reason that the current study examines the influence that general deterrence and the threat of sanction can have on promoting young people's internal motivations to comply with road rules.

Road policing relies heavily on the principles outlined in deterrence theory (Bates et al., 2012). Deterrence theory can be traced back to the theorists Cesare Beccaria and Jeremy Bentham, who both posited that non-compliance is able to be prevented through the threat and understanding of punishment (Samuels, 1969, Anderson et al., 1983, Akers and Sellers, 2004). Hence, in the driving context, compliance with driving laws is shaped by public perceptions of deterrence measures and the understanding of punishment for violating those laws.

Deterrence theory points to the value of punishment being severe, certain and swift (Grasmick and Bursik, 1990, Piquero and Pogarsky, 2002). The severity of punishment refers to the perceived expected magnitude of the sanction if it were imposed on an individual (Grasmick and Bursik, 1990, Piquero and Pogarsky, 2002). Akers (1994) suggested that decisions are made using a rational choice, and when contemplating performing a noncompliant act the expected severity of the potential punishment is considered. The certainty of punishment refers to the likelihood of being caught and punished (Grasmick and Bursik, 1990, Piquero and Pogarsky, 2002, Blais and Bacher, 2007). The probability of punishment 
for a crime is more effective if the potential offender perceives there to be a high probability of being caught (Akers and Sellers, 2004). The celerity (or swiftness) of punishment refers to how soon after the commission of a crime the punishment is applied (Piquero and Pogarsky, 2002, Akers and Sellers, 2004). The more immediate the punishment, the more effective it is at deterring future behaviour (Akers, 1994). Akers and Sellers (2004) argue that if the sanction for a crime is severe, certain, and swift then an individual would rationally determine, using a cost-benefit analysis, that the cost of committing a crime is too risky and will therefore be deterred from offending.

Further, are the two ways in which deterrence are intended to operate (Akers and Sellers, 2004). Offenders who are certainly caught and severely punished are targeted with specific deterrence (Akers and Sellers, 2004); their apprehension and punishment serves to deter them from future re-offending. General deterrence, on the other hand, is where the punishment of offenders serves as an example to others; fear of being punished in a similar fashion serves to deter an individual from offending (Akers and Sellers, 2004).

One last point is worth noting. Deterrence and enforcement of driving noncompliance can also occur through both formal and informal mechanisms. While formal deterrence concerns have been addressed in tackling young driver compliance, namely police enforcement, other sources of deterrence and enforcement, such as informal deterrence and sanctioning imparted by parents and peers, tend to be overlooked when developing driving laws and restrictions (Goodwin et al., 2006). This oversight is important because as mentioned earlier, social and family factors have been shown to play an important role in deterring young drivers from violating road rules (see Taubman - Ben-Ari and Katz - BenAmi, 2012). The current study will focus on the role that general deterrence plays in reducing young drivers' road non-compliance behaviour, particularly the role that parental and police sanctioning can play in contributing to young drivers' fear of punishment. 
Some prior studies have examined how police and formal rules can influence driver behaviour. For example, Blais (2013) used deterrence theory to understand whether traffic infringements are perceived as punishment in Canada. Fleiter et al. (2006) examined how drivers avoid punishment in the context of speeding. Nagin (1998) used deterrence theory to assess the initial and subsequent 'decay' effect of deterrence in regards to drunk driving sanctions. Homel (1994) examined whether the use of random breath testing and increased public awareness campaigns of drunk driving provided a deterrent effect for drivers in NSW, Australia. Each of the studies revealed that formal sanctions could deter various illegal driving behaviours. However, it appears as if formal deterrence may not work as effectively with young drivers. A study with Australian provisional drivers identified an 'emboldening' effect with those drivers who have previously been caught committing a driving offence are more likely to report lower levels of compliance (Bates et al., in press).

While formal sanctioning mechanisms can deter would-be offenders from breaking rules, Grasmick and Bursik (1990) point to the value of including both formal and informal sanctioning mechanisms for promoting compliance with the law. Grasmick and Bursik (1990) argue that the state-imposed sanctions that one experiences when receiving punishment is a formal deterrence measure (Grasmick and Bursik, 1990). This state imposed form of deterrence can include fines, incarceration, and the expectation that formal punishment enacted by police and the law will be severe and certain (Grasmick and Bursik, 1990). Informal deterrence, in contrast, is largely based on the concept of informal social control and social bonding and the socially-imposed embarrassment and self-imposed shame experienced by individuals if they are non-compliant (Anderson et al., 1977). Grasmick and Bursik (1990) theorised that shame emotions imposed by significant others and one's self are important factors that contribute to the effectiveness of informal deterrence measures.

Anderson et al. (1977) identified that informal social control, which is often influenced by family or neighborhood structures, can in fact have a stronger impact on 
deterring wrong-doing than formal sanctioning imparted by the state. This is because family and neighborhood structures aid in developing one's values and views pertaining to social and legal norms (Anderson et al., 1977). The shame imposed by family, or significant others (e.g. girlfriend) over wrong-doing is seen to be more effective in deterring inappropriate behaviour than official sanctions by police and the law because the judgement of significant others, particularly significant authoritative figures, matters more to an individual (Akers, 1994).

In other words, both general and specific deterrence is more effective if imposed by significant others such as parents, because such disapproval is more likely to invoke feelings of shame in the wrong-doer (Akers, 1994, Foss and Goodwin, 2003, Goodwin and Foss, 2004). Such shame results in a greater personal cost associated with law breaking. Thus, parents might be more effective than police in deterring non-compliant driving behaviour among young drivers (Foss and Goodwin, 2003, Goodwin and Foss, 2004). There is empirical evidence to support that this may occur in other contexts. For example, in their study of tax offenders Murphy and Helmer (2013) found that state-imposed punishment was less effective at producing shame emotions over tax offending and was less effective for fostering subsequent compliance than disapproval of non-compliance communicated by a family member.

\section{Present study}

While deterrence theory has been tested to investigate the field of driving behaviour and road use, most of these studies have focused on formal aspects of deterrence (see Nagin, 1998, Watson, 2004, Fleiter and Watson, 2006, Elliott, 2008, Blais, 2013). Very few studies have examined how informal deterrence mechanisms influence compliance with road rules (see Grasmick and Bursik, 1990, Ahmed et al., 2001). No study to date has specifically examined 
how informal deterrence mechanisms can influence young drivers' compliance with road rules, and specifically those drivers restricted by GDL provisions.

Given this research gap, the present study seeks to compare the effects of both formal and informal forms of general deterrence on young driver's compliance with GDL restrictions and general road rules. It seeks to understand the perceptions of provisionally licensed drivers regarding their perceived likelihood of detection and punishment by police and parents, and importantly how this influences their subsequent driving compliance behaviour. We specifically examine these issues within the context of the GDL system in Queensland, Australia.

Based on the literature reviewed above, we expect that informal sanctions might have a stronger effect than formal sanctioning in predicting young drivers' compliance behaviour because of the social costs imposed by such punishment. In order to explain why this may be so, we will also examine how shame emotions may mediate the effect of informal sanctions, but not formal sanctions, on self-reported driving compliance behaviour. The following three hypotheses will be tested:

H1) Both informal and formal sanctions will improve the self-reported driving compliance of young provisionally licensed drivers;

H2) Informal sanctions will have a greater effect than formal sanctioning on feelings of shame and on provisional drivers' compliance with road rules and GDL restrictions;

H3) Shame emotions will mediate the effect of informal sanctioning, but not formal sanctioning, on driving compliance.

Before we lay out the methodology adopted in our study to test these hypotheses, we first briefly outline how the GDL system operates in Queensland, Australia. 


\section{The Queensland GDL system}

GDL was introduced into a range of countries including the US, Canada, New Zealand and Australia as a public health measure to reduce injuries and fatalities along with a range of countermeasures targeted at this age group (e.g. driver education and training). The current three-stage GDL scheme in Queensland, Australia was first implemented in 1999 with the aim of reducing novice drivers' crash risk and to increase police enforcement of young novice drivers (Parliamentary Travelsafe Committee, 2003, Senserrick and Whelan, 2003, Bates, 2012). The scheme was modified in 2007, so that novice drivers were required to pass through a learners stage and two provisional licence stages prior to obtaining an open licence (Bates, 2010, Bates, 2012). A learner’s licence can be obtained following a written exam at the age of 16 years. It must be held until the driver turns 17 after which time they are eligible to sit a practical driver exam to obtain a provisional licence. Drivers who are provisionally licensed in Queensland go through two stages of a provisional licence, the Provisional 1 (P1 for 12 months minimum) and the Provisional 2 (P2 - for 24 months minimum) licence. Those on a P1 licence are aged at a minimum 17 years old, and they have an alcohol restriction placed upon them of $0.00 \%$ blood alcohol concentration. Furthermore, P1 licensed drivers are not permitted to use a cell phone while driving, drive with more than one peer passenger during the hours of (11pm to 5am), and can only accumulate three demerit points if found violating road rules ${ }^{1}$. Those who graduate to a P2 licence 12 months later are only restricted by the $0.00 \%$ blood alcohol concentration limit. An important restriction that was introduced following the 2007 changes to the Queensland GDL scheme was the requirement for all newly licensed drivers to display a P-plate on a vehicle when being operated by them (red plate for P1; green plate for P2). These visible plates are placed in the corners of the front and rear windshields and indicate to the public and police that the driver is on a

\footnotetext{
${ }^{1}$ Once three demerit points are accumulated the driver may lose their licence. Drivers on an open licence are able to accumulate 12 demerit points before possibly losing their licence.
} 
provisional licence and therefore has certain restrictions. This additional restriction on novice drivers has only been implemented outside of Australia in New Jersey, USA, where a small decal is placed on the car licence plate to distinguish restricted drivers from open licensed drivers (McCartt et al., 2012). While our study is situated within the Queensland GDL scheme, there are similarities among the Queensland GDL system and the GDL system in other states and territories in Australia. They licence at similar ages, require learners to be supervised and impose restrictions on the provisional phase (see Senserrick, 2007 for a comparison of GDL systems between states in Australia).

\section{Methods}

A total 200 young people in Brisbane, Australia volunteered to complete a survey on their driving behaviour. However, several respondents were excluded as they did not meet the requirements for this study (e.g., they reported not having a provisional driver licence, $\mathrm{N}=21$ ), or they did not submit a fully completed survey resulting in a large amount of missing data $(\mathrm{N}=28)$. This left 151 useable surveys. This sample size was considered sufficient to address the research questions. The final sample was aged between 17 and 25 years $(\mathrm{M}=$ $19.50, \mathrm{SD}=1.89)$ and $82 \%$ were female. Given the average age of respondents, the majority of the sample (61.6\%) was on their Provisional 2 (P2) licence.

Survey data was collected between May and August, 2013. Recruitment of participants included approaching students at three Brisbane universities, through social media networking, and placing recruitment flyers on vehicles that displayed P-plates. An incentive of a $\$ 50$ voucher to be won in a prize draw was used to encourage response rates. Anonymity of respondents was also guaranteed to encourage honest survey responses regarding driving behaviour (see Lajunen and Summala, 2003).

The survey used several multiple item scales designed to measure the elements of deterrence, shame, and compliance. The items used to measure the scales were adapted from 
previous research with slight modification to ensure consistency and applicability (see Table 1 for a list of survey items used). Within this study, the independent variables were formal deterrence by police, informal deterrence by parents, and shame-related emotion elicited in response to driving non-compliance. 'Formal deterrence' was measured using four items, each designed to assess drivers' perceived likelihood of being caught and sanctioned by police for violating road rules. The four-item 'informal deterrence' scale assessed the perceived likelihood of being caught and sanctioned for violating road rules by parents. The five-item 'shame' scale measured the respondents' anticipated feelings of shame and embarrassment if they were to be caught violating road rules.

Two different measures of compliance were used as dependent variables. The first four-item compliance measure assessed whether young drivers complied with long-standing 'entrenched' road rules (e.g. not driving under the influence of alcohol; wearing a seat belt; stopping at a red light). The second five-item compliance measure assessed self-reported compliance with less established 'new' road rules (e.g., not using a cell phone while driving).

The questions used for the deterrence and shame-related emotion scales (adapted from Grasmick and Bursik, 1990, Wenzel et al., 2004, Bates, 2012) were measured on a $1=$ strongly disagree to $5=$ strongly agree Likert scale. Higher scores on each of the scales therefore reflected greater self-reported shame in response to potential wrong-doing and greater perceptions of the probability of informal and formal sanctioning. The 'entrenched' and 'new' compliance scales (adapted from Murphy, 2005, Ivers et al., 2009, Bates, 2012) were measured on a $1=$ never to $5=$ always scale, with higher scores indicating greater compliance.

To investigate whether the constructed scales had discriminant validity, the scales were subject to a principal components factors extraction with a varimax rotation (see Table 1). The factor analysis yielded a five-factor solution, and explained $61.35 \%$ of the variance. All of the 22 items loaded as expected onto their respective factor, with the exception of two 
items. Despite the cross loadings to other factors, the two items were retained in their respective factors as the cross loadings were considered to be weak, and conceptually they were more appropriate with the factor to which they were assigned.

In addition to the scales, four control variables were also used. These variables were gender $(0=$ male; $1=$ female), age, licence type $(0=\mathrm{P} 1,1=\mathrm{P} 2)$, and number of months a licence had been held.

\section{[Insert Table 1]}

Table 2 presents the means, standard deviations, and Cronbach's reliability coefficients for each scale. The mean scores reveal that respondents generally reported being compliant with road rules. The mean scores for the informal and formal deterrence scales also revealed that respondents were not overly concerned about being caught and punished by police or parents. The high mean score for the shame scale reveals that respondents were likely to feel shame over wrong-doing.

\section{[Insert Table 2]}

\section{Results}

Three hierarchical regressions were conducted to test our three hypotheses: H1) both informal and formal sanctions will improve self-reported driving compliance behaviour; H2) informal sanctioning will have a greater effect than formal sanctioning on feelings of shame and compliance; and H3) shame-related emotions will mediate the effects of informal sanctioning, but not formal sanctions, on driving compliance.

The first analysis used the control variables and the two deterrence measures to predict shame. This regression was performed to demonstrate that formal and informal sanctions could invoke shame-related emotions over potential wrong-doing. This relationship is necessary in order to demonstrate that shame can mediate the effect of 
deterrence on compliance (see Baron and Kenny, 1986). As can be seen in Table 3, the first step in the analysis explained $11 \%$ of the variance in shame-related emotion. Step 1 reveals that gender, but no other control variables, is associated with feelings of shame; specifically, females were more likely than males to express that they would feel shame if caught violating road rules. In Step 2, the two deterrence scales were added. Here, the model explained 28\% of the variance in shame-related emotion. Gender continued to exert an effect on shame, but importantly, both the formal and informal deterrence measures also predicted feelings of shame. Those respondents who were more likely to believe the police and their parents would catch them violating road rules were more likely to express that they would feel shame if caught violating road rules. Of the two deterrence measures, informal deterrence was slightly more important than formal deterrence in predicting shame, although Paternoster et al's (1998) test for equality of regression coefficients showed that the two regression coefficients did not differ significantly from one another $(z=.45, p>.05)$.

[Insert Table 3]

Table 4 uses the control variables, informal and formal deterrence, and shame scales as predictors of compliance with 'new' road rules. As can be seen in Step 1 of the analysis, both gender and licence type were significant predictors of self-reported compliance with the new road rules. Females, and those on a P1 licence, reported greater levels of compliance supporting prior research in the field. Once the deterrence measures were entered in the model at Step 2, however, the effects of gender and licence type on compliance disappeared. Step 2 reveals that informal, but not formal, deterrence predicted compliance, suggesting that parental enforcement of road rules can predict higher compliance with new road rules (again, however, the equality of regression coefficients calculation revealed no significant difference between the size of the coefficients, $z=.70, p>.05$ ). Step 3 of the model contained all seven variables, which included the addition of shame, and explained $25 \%$ of the variance in 
compliance with new rules. In this final model, only shame-related emotion was statistically significant $(\beta=.24, p<.01)$; those who expressed they would feel more shame over wrongdoing were more likely to report being compliant with new road rules. Interestingly, informal deterrence no longer predicted compliance in Step 3, suggesting that shame mediated the effect of informal deterrence on compliance. A Sobel test confirmed that this mediation effect was significant, $z=2.10, p<.05$.

\section{[Insert Table 4]}

Table 5 displays the regression analysis showing compliance with 'entrenched' road rules. Interestingly, none of the control variables, nor the informal or formal deterrence measures, predicted young drivers' compliance with entrenched road rules at Step 1 and 2. It can be seen again in Step 3 that feelings of shame appear to be more important for preventing non-compliance than deterrence. Such a finding suggests that internal morals and the emotions of shame they elicit over wrong-doing are more effective in producing compliant behaviour with road rules.

\section{[Insert Table 5]}

\section{Discussion}

GDL schemes require newly licensed drivers to adhere to additional driving requirements when compared with more experienced drivers. However, to ensure compliance with these road rules, authorities and parents around the world need to be able to deter any violations of road rules and licensing restrictions that may increase the crash risk for the driver (Foss and Goodwin, 2003). Until now there has been limited research that has examined the impact of deterrence measures on road traffic compliance for novice drivers who are subject to a graduated driver licensing system. Specifically, the relative effects of formal detection by police and informal detection by parents has not been studied. It is important to examine the 
impact of both formal and informal forms of deterrence, given that formal deterrence appears of limited benefit in increasing young driver compliance with road traffic laws (Bates et al., in press) and that the criminology literature suggests that deterrence mechanisms may operate through shame and embarrassment, with shame being more likely to be elicited by loved ones (Grasmick and Bursik, 1990).

Hence, the aim of the present study was to examine the impact that both formal and informal deterrence had on young provisionally licensed drivers' road compliance behaviour. Three hypotheses were tested. We first predicted that both formal and informal deterrence would increase self-reported driving compliance behaviour (Hypothesis 1). Second, we predicted that informal deterrence would have a greater impact than formal deterrence on both shame emotions and compliance behaviour (Hypothesis 2). Finally, we tested the hypothesis that shame would mediate the relationship between informal deterrence and compliance, but not between formal deterrence and compliance.

To summarise, we found that informal deterrence was important in predicting compliance with the 'new' rules: those respondents who were more likely to believe they would be caught and punished by their parents for violating road rules were more likely to report they would be compliant with 'new' road rules. This result suggests that parents have a role to play in deterring driving non-compliance. Across both compliance measures used within this study, formal deterrence was not a significant predictor of compliance behaviour. Together, these findings suggest informal deterrence matters more than formal deterrence when predicting young drivers' compliance in our context. Thus, Hypothesis 1 was partially supported and Hypothesis 2 was fully supported.

The role of shame-related emotion and its relationship to deterrence for predicting compliance was interesting. First, shame was found to be a strong predictor for both compliance measures: the more shame a respondent indicated they would feel in response to wrong-doing the more compliant they reported they would be. More importantly, however, 
shame was found to mediate the effect of informal deterrence on compliance behaviour. Specifically, shame mediated the effect of informal deterrence on compliance with the 'new' road rules. Given formal deterrence was unrelated to compliance behaviour in our study; shame could not mediate its effect on compliance. Hence, Hypothesis 3 was supported. Together, these findings are consistent with past research. In the context of young driver compliance research, Taubman - Ben-Ari and Katz - Ben-Ami (2012) found that parents were particularly influential in shaping their children’s driving compliance behaviour.

One of our findings warrants additional attention. We found that compliance with 'entrenched' road rules was not predicted by either formal or informal deterrence. We suggest this could have something to do with the nature of the behaviours being measured in our 'entrenched' compliance scale (e.g. not drinking and driving, ensuring one wears a seatbelt, not running a red light). One could argue that adherence to such rules has become normative, with few people questioning the importance of following such rules. For example, it has been well established that drunk driving can kill (Steinbock, 1985), so the majority of drivers recognise this and thus will comply with the law restricting such behaviour. Not using a cell phone while driving (which formed part of our 'new' compliance scale), in contrast, has not yet achieved the same status in our psyche. It is one type of behaviour that receives mixed reactions regarding the risk to safety it poses (Nemme and White, 2010). Given the normative status of the 'entrenched' rules, drivers are likely to have internalised the moral value of following such rules. This explains why deterrence may not have influenced this outcome; people will comply with such rules regardless of whether a formal or informal deterrent is present or not. This may also explain why shame was still pertinent to influencing respondents’ compliance with entrenched road rules. Intrinsic moral values appear to be shaping such behaviour, with recognition that failure to comply with such normative rules will bring shame upon the offender. 
It is also worth considering what demographic and background factors were important in our study for understanding compliance. Our findings show that males were less likely than females to be compliant with road laws, although it should be noted that this effect disappeared when considering the deterrence and shame measures. This finding also supports past literature, suggesting males tend to be less compliant than females (Curry et al., 2013). Interestingly, gender was also a significant predictor of shame-related emotion and this effect remained significant even after including the deterrence measures into the model; females were more likely to experience shame-related emotion than males.

Our more experienced P2 drivers were also found to be more non-compliant with new road rules. These findings suggest that the further a driver progresses through the GDL system, the less compliant they become. This finding supports the literature, which finds that from beginner learner licensing through to more experienced P2 licensed drivers, compliance reduces (Scott-Parker et al., 2012). This is perhaps not surprising, however, given that P2 licensed drivers have been on the road longer, thereby increasing the probability they will be detected violating road rules. Non-compliance here may therefore have more to do with the time spent on the road than due to a relaxing of compliance behaviour. Once perceptions of deterrence are accounted for, however, license type no longer has an effect on compliance.

\section{Implications for deterrence theory and policing of GDL schemes}

As noted in the Introduction, deterrence theory has informed the development of much of our road traffic policing. Police enforce road rules through strategies that aim to create a credible risk of sanction for wrong-doing. However, more recent theorising has proposed that informal deterrence, not formal deterrence, is most likely to impact upon behaviour. Researchers have claimed that those who have significant relations and social bonds to would-be offenders are more likely to have success in deterring their non-compliance because they are more likely to elicit internal feelings of shame over wrong-doing among the recipient 
(Grasmick and Bursik, 1990, Homel, 2004, Murphy and Helmer, 2013). Indeed our findings support this claim. We find that across all three forms of compliance, formal deterrence was not directly related to compliance. Instead, we find that parents were more likely than police to deter driver non-compliance. We suggest parents might be more effective in deterring young drivers' non-compliant behaviour because they have the ability to withhold driving privileges from their children if those children are caught violating road rules (e.g. withholding keys or access to car). We also suggest that parents are more effective in doing so because they have closer social bonds with the young person, which results in a greater likelihood of eliciting feelings of shame in the young driver. Hence, the key psychological mechanism that appears crucial for explaining why informal deterrence is particularly effective in shaping compliance behaviour is shame. Shame dominated people's compliance behaviour in our study, and informal deterrence was able to influence compliance through the mediating influence of the shame-related emotions that young drivers felt in response to parental enforcement.

Given that formal policing deterrence strategies appear to be largely ineffective in shaping young driver compliance in our study, we suggest that police need to consider alternative approaches that better speak to the internal motivators of young drivers' compliance behaviour. Simply increasing the probability of detection and severity of formal sanctions is unlikely to reduce the risk of serious crashes among young drivers. This is not to suggest that police have no role to play in shaping driver behaviour. Clearly we found that formal deterrence was linked to shame, with shame playing a dominant role in predicting compliance. However, police cannot be everywhere at all times to deter or detect noncompliance on the roads. Given this, our findings suggest police need to rely upon strategies that elicit young people's internal motivations to comply with road rules. This might be better achieved through education campaigns or through working more closely with parents. For example, a major part of policing involves forging partnerships with third parties in an 
effort to control crime. 'Third party policing' is an approach whereby police co-opt or coerce organisations or individuals to work with them to tackle a crime control issue (Mazerolle and Ransley, 1998, Mazerolle and Ransley, 2005, Mazerolle and Ransley, 2006). This form of policing may use civil, criminal and/or regulatory laws to engage third-parties (also known as proximate targets) such as parents, into taking some crime control responsibility in a shared problem (also known as ultimate targets), such as anti-social behaviour among young people, gang members, or drug dealers (Mazerolle and Ransley, 2005). These third-parties have been shown to have some influence over the behaviour of target individuals or groups and research has demonstrated that this form of policing can be very effective (see Mazerolle and Ransley, 2006). In fact, third-party policing has been used effectively between police, parents and young people (see Mazerolle and Ransley, 2006).

A formal third-party policing program where police work in partnership with parents in monitoring young drivers might therefore prove very effective in increasing young drivers' compliance on the road. Recently, it was reported in the media that installing cameras on young drivers' cars has been adopted as one technique for such parental monitoring (Doheny, 2013). Of course, for such a program to be successful, parental monitoring of provisionally licensed drivers largely depends on parents taking an active interest in the behaviour of their children on the road, and seeing through a commitment to withhold driving privileges from young drivers if they are detected doing the wrong thing.

\section{Limitations and future research}

Before concluding, it is important that we highlight a few limitations of our study that should be taken into account when interpreting the results. First, the sample used within our study was comprised predominantly of university-educated students, who assumedly come from middle-class, stable families, where parents are more likely to take an active interest in their welfare. Had we sampled a broader cross-section of the community in our study, the results 
may have been different, particularly in relation to the importance of parents in deterring noncompliance. Furthermore, a large proportion of participants were female, given that novice male drivers are riskier drivers than novice female drivers, the results may show different effects on compliance if there was a more equal distribution of females and males sampled. Second, the survey data upon which we draw is cross-sectional in nature. We found that informal deterrence and shame predicted self-reported compliance behaviour. However, it is equally plausible from our findings that non-compliant individuals are less likely to report feeling shame or are less likely to see deterrence as an issue. The direction of causality between our variables is therefore obscured when we use cross-sectional data. In order to determine whether informal deterrence and shame are true predictors of compliance, longitudinal data or an experimental methodology will need to be adopted to tease apart the relationships between our variables. Third, some of our measures can be criticised. The Cronbach alpha reliability coefficients for the 'new' and 'entrenched' compliance measures were low, therefore calling into question the validity of our compliance scales. Furthermore, the concept of severity in the deterrence literature was not captured in our study; only the perceived certainty and celerity of sanctioning were measured (although, other scholars have suggested that severity is not as effective compared to perceived certainty and celerity of punishment in deterring would-be offenders (Nichols and Ross, 1990).

While additional research using different research designs and samples would be beneficial in overcoming these limitations, future research could also expand on the findings of this study. From a theoretical perspective, this study has demonstrated the importance of informal deterrence, particularly when mediated by shame, for this group within a driving context. Future research could examine if these findings generalise to other age groups of drivers and across alternative contexts. Given the finding that formal deterrence does not appear as important in encouraging newly licensed drivers to comply with road laws, there is a need to identify the processes used, or not used, by police to increase compliance within 
this driver sub-group. This study suggests that third-party policing may be one approach that could be used to increase compliance with the road laws by this group. Future research could explore this possibility further.

\section{Conclusion}

This study examined the effect of formal deterrence, operationalised as perceptions of police sanctioning, and informal deterrence, operationalised as perceptions of parental sanctioning, on newly licensed drivers' compliance with traffic laws. The findings suggest that informal deterrence mechanisms are more effective than formal deterrence, particularly when mediated by shame emotions. These findings indicate the importance of informal social control in shaping young driver behaviour.

Additionally, this study has significant implications for the policing of young drivers in order to increase their compliance with traffic laws and thus, reduce their crash risk. Given that informal deterrence appears to be more important than formal deterrence in encouraging compliant behaviour, there may be scope to work with parents to encourage young drivers to adhere to traffic laws. This may be done using a third-party policing framework. Additionally, police may need to examine the processes that they currently use with young drivers within this context as there may be scope to increase the benefits of their work within this area. 


\section{References}

Ahmed, E., Harris, N., Braithwaite, J. \& Braithwaite, V., 2001. Shame management through reintegration Cambridge, United Kingdom: Cambridge University Press.

Akers, R., 1994. Criminological theories: Introduction and evaluation Los Angeles, California: Roxbury Publishing.

Akers, R. \& Sellers, C., 2004. Criminological theories: Introduction, evaluation and application, 4th ed. California, USA: Roxbury Publishing Company.

Anderson, A., Harris, A.R. \& Miller, J., 1983. Models of deterrence theory. Social Science Research, 12, 236-262.

Anderson, L., Chiricos, T. \& Waldo, G., 1977. Formal and informal sanctions: A comparison of deterrent effects. Social Problems, 25, 103-114.

Baron, R. \& Kenny, D., 1986. The moderator-mediator variable distinction in social psychological research: Conceptual, strategic, and statistical considerations. Journal of Personality and Social Psychology, 51, 1173-1182.

Bates, L., 2010. Parliamentary committees are important in developing policy: evidence from a Queensland case study. Australasian Parliamentary Review, 25, 14-26.

Bates, L., 2012. The experience of learner driver, provisional drivers and supervisors with graduated driver licensing in two Australian jurisdictions. Queensland University of Technology.

Bates, L., Allen, S., Armstrong, K., Watson, B., King, M. \& Davey, J., 2014a. Graduated driver licensing: An international review. Sultan Qaboos University Medical Journal, $14,432-441$.

Bates, L., Darvell, M. \& Watson, B., in press. Does an extended model of deterrence theory offer explanation for provisional drivers' compliance with graduated driver licencing provisions? Australian \& New Zealand Journal of Criminology. 
Bates, L., Davey, J., Watson, B., King, M. \& Armstrong, K., 2014b. Factors contributing to crashes among young drivers. Sultan Qaboos University Medical Journal, 14, e297305.

Bates, L., Soole, D. \& Watson, B., 2012. The effectiveness of traffic policing in reducing traffic crashes. In T. Prenzler (ed.) Policing and security in practice: Challenges and achievements. England, United Kingdom: Palgrave Macmillan, 90-109.

Begg, D. \& Stephenson, S., 2003. Graduated driver licensing: the New Zealand experience. Journal of Safety Research, 34, 99-105.

Blais, E., 2013. On the importance of environments and contexts in deterrence research: the case of traffic infringements. Griffith University. Mt Gravatt, Queensland.

Blais, E. \& Bacher, J.-L., 2007. Situational deterrence and claim padding: results from a randomized field experiment. Journal of Experimental Criminology, 3, 337-352.

Curry, A.E., Pfeiffer, M.R., Localio, R. \& Durbin, D.R., 2013. Graduated driver licensing decal law: Effect on young probationary drivers. American Journal of Preventive Medicine, 44, 1-7.

Doheny, K., 2013. Car tracking devices for teen drivers: Monitoring can help, but it doesn't replace communication [online]. Edmunds. Available from: www.edmunds.com/cartechnology/tracking-teen-drivers.html. [Accessed Access Date 2013].

Elliott, B., 2008. Can we rely on Deterrence Theory to motivate safe road user behaviour? ARCS-Travelsafe National Conference. Brisbane, Queensland: Queensland Parliament, Australia.

Elvik, R., 2010. Why some road safety problems are more difficult to solve than others. Accident Analysis \& Prevention, 42, 1089-1096.

Fleiter, J. \& Watson, B., 2006. The speed paradox: the misalignment between driver attitudes and speeding behaviour. Journal of Australasian College of Road Safety, 17, 23-30. 
Fleiter, J., Watson, B., Lennon, A. \& Lewis, I., 2006. Significant others, who are they? Examining normative influences on speeding. Proceedings 2006 Australiasian Road Safety Research Policing Education Conference. Gold Coast, Queensland.

Foss, R., Feaganes, J. \& Rodgman, E., 2001. Initial effects of graduated driver licensing on 16-year-old driver crashes in North Carolina. Journal of American Medical Association, 286, 1588-1592.

Foss, R. \& Goodwin, A., 2003. Enhancing the effectiveness of graduated driver licensing legislation. Journal of Safety Research, 34, 79-84.

Ginsburg, K.R., Winston, F.K., Senserrick, T.M., García-España, F., Kinsman, S., Quistberg, D.A., Ross, J.G. \& Elliott, M.R., 2008. National young-driver survey: Teen perspective and experience with factors that affect driving safety. Pediatrics, 121, 1391-1403.

Goodwin, A. \& Foss, R., 2004. Graduated driver licensing restrictions: awareness, compliance, and enforcement in North Carolina. Journal of Safety Research, 35, 367374.

Goodwin, A., Wells, J., Foss, R. \& Williams, A., 2006. Encouraging compliance with graduated driver licensing restrictions. Journal of Safety Research, 37, 343-351.

Grasmick, H.G. \& Bursik, R.J.J., 1990. Conscience, significant others, and rational choice: Extending the Deterrence model. Law \& Society Review, 24, 837-861.

Hedlund, J., 2007. Novice teen driving: GDL and beyond. Journal of Safety Research, 38, 259-266.

Homel, R., 1994. Drink-driving law enforcement and the legal blood alcohol limit in New South Wales. Accident Analysis \& Prevention, 26, 147-155.

Homel, R., 2004. Drivers who drink and rational choice: Random breath testing and the process of deterrence. In R.V. Clarke \& M. Felson (eds.) Routine activity and rational 
choice: Advances in criminological theory. New Jersey: Transaction Publishers, 5984.

Ivers, R., Senserrick, T., Boufous, S., Stevenson, M., Chen, H.-Y., Woodward, M. \& Norton, R., 2009. Novice drivers' risky driving behavior, risk perception, and crash risk: findings from the DRIVE study. American Journal of Public Health, 99, 1638-1644.

Lajunen, T. \& Summala, H., 2003. Can we trust self-reports of driving? Effects of impression management on driver behaviour questionnaire responses. Transportation Research Part F: Traffic Psychology and Behaviour, 6, 97-107.

Lyon, J., Pan, R. \& Li, J., 2012. National evaluation of the effect of graduated driver licensing laws on teenager fatality and injury crashes. Journal of Safety Research, 43, 29-37.

Masten, S.V. \& Foss, R.D., 2010. Long-term effect of the North Carolina graduated driver licensing system on licensed driver crash incidence: a 5-year survival analysis. Accident Analysis and Prevention, 42, 1647-52.

Mayhew, D.R., Simpson, H.M. \& Pak, A., 2003. Changes in collision rates among novice drivers during the first months of driving. Accident Analysis \& Prevention, 35, 683691.

Mazerolle, L. \& Ransley, J., 1998. Third-party policing: prospects, challenges and implications for regulators. In R. Johnstone \& R. Sarre (eds.) Regulation: Enforcement and compliance. Canberra: Australian Institute of Criminology. Mazerolle, L. \& Ransley, J., 2005. Third party policing. United States of America: Cambridge University Press.

Mazerolle, L. \& Ransley, J., 2006. The case for third-party policing. In D. Weisburd \& A. Braga (eds.) Police Innovation: Contrasting Perspectives. Cambridge, England: Cambridge University Press. 
Mccartt, A., Mayhew, D.R., Braitman, K., Ferguson, S. \& Herbert, S., 2009. Effects of age and experience on young driver crashes: Review of recent literature. Traffic Injury Prevention, 10, 209-219.

Mccartt, A., Teoh, E., Fields, M., Braitman, K. \& Hellinga, L., 2010. Graduated licensing laws and fatal crashes of teenage drivers: A national study. Traffic Injury Prevention, $11,240-248$.

Mccartt, A.T., Oesch, N.J., Williams, A.F. \& Powell, T.C., 2012. New Jersey's license plate decal requirement for graduated driver licenses: Attitudes of parents and teenagers, observed decal use, and citations for teenage driving violations. Traffic Injury Prevention.

Murphy, K., 2005. Regulating more effectively: The relationship between procedural justice, legitimacy and tax non-compliance (CTSI Working Paper 71). Canberra: The Australian National University.

Murphy, K. \& Helmer, I., 2013. Testing the importance of forgiveness for reducing repeat offending. Australian and New Zealand Journal of Criminology, 46, 138-156.

Nagin, D., 1998. Criminal deterrence research at the outset of the twenty-first century. Crime and Justice, 23, 1-42.

Nemme, H. \& White, K., 2010. Texting while driving: Psychosocial influences on young people's texting intentions and behaviour. Accident Analysis \& Prevention, 42, 12571265.

Neyens, D.M., Donmez, B. \& Boyle, L.N., 2008. The Iowa Graduated Driver Licensing program: effectiveness in reducing crashes of teenage drivers. Journal of Safety Research, 39, 383-90.

Nichols, J. \& Ross, L., 1990. The effectiveness of legal sanctions in dealing with drinking drivers. Alcohol, Drugs and Driving, 6, 33-60. 
Parliamentary Travelsafe Committee, 2003. Provisional driver and rider licence restrictions. In D.O.T.a.M. Roads (ed.) Brisbane, Queensland: Queensland Government.

Paternoster, R., Brame, R., Mazerolle, P. \& Piquero, A.R., 1998. Using the correct statistical test for the equality of regression coefficients. Criminology, 36, 859-866.

Piquero, A.R. \& Pogarsky, G., 2002. Beyond Stafford and Warr's reconceptualization of deterrence: personal and vicarious experiences, impulsivity, and offending behavior. Journal of Research in Crime and Delinquency, 39, 153-186.

Pressley, J.C., Benedicto, C.B., Trieu, L., Kendig, T. \& Barlow, B., 2009. Motor vehicle injury, mortality, and hospital charges by strength of graduated driver licensing laws in 36 States. The Journal of Trauma, 67, 43-53.

Samuels, A., 1969. Principles in sentencing. Dublin University Law Review, 1, 78-87.

Scott-Parker, B., Watson, B., King, M. \& Hyde, M., 2012. Young, inexperienced and on the road: do novice drivers comply with road rules? Journal of the Transportation Research Board, 2318, 98-106.

Senserrick, T., 2007. Recent developments and young driver education, training and licensing in Australia. J Safety Res, 38, 237-44.

Senserrick, T. \& Whelan, M., 2003. Graduated driver licensing: Effectiveness of systems and individual components. Victoria, Australia: R.C. (Vicroads).

Shope, J.T., 2007. Graduated driver licensing: Review of evaluation results since 2002. Journal of Safety Research, 38, 165-175.

Steinbock, B., 1985. Drunk Driving. Philosophy \& Public Affairs, 14, 278-295.

Taubman - Ben-Ari, O. \& Katz - Ben-Ami, L., 2012. The contribution of family climate for road safety and social environment to the reported driving behavior of young drivers. Accident Analysis \& Prevention, 47, 1-10. 
Watson, B., 2004. How effective is deterrence theory in explaining driver behaviour: A case study of unlicensed driving. Proceedings Road Safety Research, Policing and Education Conference. Perth, WA.

Wenzel, M., Murphy, K., Ahmed, E. \& Mearns, M., 2004. Preliminary findings from 'The what's fair and what's unfair survey about justice issues in the Australian tax context' (CTSI Working Paper 59). Canberra, Australia: The Australian National University.

Whelan, M., Scully, J. \& Newstead, S., 2009. Vehicle safety and young drivers. Victoria, Australia: Monash University: Accident Research Centre.

Williams, A., Tefft, B. \& Grabowski, J., 2012. Graduated driver licensing research, 2010present. Journal of Safety Research, 43, 195-203.

World Health Organisation, 2007. Youth and Road Safety. Geneva, Switzerland.

World Health Organisation, 2009. Global status report on road safety: Time for action. Geneva, Switzerland. 
Table 1

Factor analysis using Varimax rotation to differentiate the variables $(N=151)$

\begin{tabular}{|c|c|c|c|c|c|}
\hline \multirow[b]{2}{*}{ Item (\# reversed scored) } & \multicolumn{5}{|c|}{ Factor } \\
\hline & 1 & 2 & 3 & 4 & 5 \\
\hline \multicolumn{6}{|l|}{ 1. Shame-related emotion } \\
\hline $\begin{array}{l}\text { If I were caught by police for breaking the road rules, } \\
\text { I would feel embarrassed }\end{array}$ & .86 & & & & \\
\hline $\begin{array}{l}\text { I would feel embarrassed if police stopped me for } \\
\text { breaking the road rules }\end{array}$ & .85 & & & & \\
\hline $\begin{array}{l}\text { I would feel ashamed of myself if I was caught by } \\
\text { the police for breaking the road rules }\end{array}$ & .76 & & & & \\
\hline $\begin{array}{l}\text { If I were caught by police for breaking the road rules, } \\
\text { I would feel embarrassed in front of my parents }\end{array}$ & .69 & & & & \\
\hline $\begin{array}{l}\text { I would feel ashamed of myself if I was caught by } \\
\text { my parents for breaking the road rules }\end{array}$ & .66 & $(.42)$ & & & \\
\hline \multicolumn{6}{|l|}{ 2. Informal deterrence (parents) } \\
\hline $\begin{array}{l}\text { My parents are likely to punish me if I break the road } \\
\text { rules }\end{array}$ & & .87 & & & \\
\hline $\begin{array}{l}\text { I would be punished quickly by my parents if they } \\
\text { found out I was breaking the road rules }\end{array}$ & & .86 & & & \\
\hline There are high odds that my parents would catch me & & & & & \\
\hline $\begin{array}{l}\text { if I broke any of my provisional licence } \\
\text { restrictions }\end{array}$ & & .73 & & & \\
\hline $\begin{array}{l}\text { There are high odds that my parents would catch me } \\
\text { if I broke the road rules }\end{array}$ & & .70 & & & \\
\hline \multicolumn{6}{|l|}{ 3. Formal deterrence (police) } \\
\hline $\begin{array}{l}\text { There are high odds that I would be stopped and } \\
\text { ticketed by police if I was breaking the road rules }\end{array}$ & & & .80 & & \\
\hline $\begin{array}{l}\text { If I break the road rules, I am likely to be stopped by } \\
\text { police immediately }\end{array}$ & & & .79 & & \\
\hline $\begin{array}{l}\text { I am likely to be punished quickly by police if I get } \\
\text { caught breaking the road rules }\end{array}$ & & & 68 & & \\
\hline $\begin{array}{l}\text { It is certain that I would be caught by police if I was } \\
\text { not displaying my P-plates }\end{array}$ & & & .64 & & \\
\hline \multicolumn{6}{|l|}{ 4. Compliance (entrenched rules) } \\
\hline $\begin{array}{l}\text { Stop at red lights, even when there are no other cars } \\
\text { on the road }\end{array}$ & & & & .89 & \\
\hline Wear a seat belt & & & & .75 & \\
\hline Carry your licence with you when you drive & & & & .72 & \\
\hline Drive under the influence of alcohol\# & & & & .46 & \\
\hline \multicolumn{6}{|l|}{ 5. Compliance (new rules) } \\
\hline Use a hand-held mobile phone while driving\# & & & & & .74 \\
\hline Use a hands-free mobile phone while driving\# & & & & & .66 \\
\hline $\begin{array}{l}\text { Allow passengers to use a mobile phone while } \\
\text { driving\# }\end{array}$ & & & & & .64 \\
\hline Exceed the signed speed limit by more than $10 \mathrm{~km} / \mathrm{h} \#$ & $(.45)$ & & & & .56 \\
\hline $\begin{array}{l}\text { Drive with more than one passenger (non-family, } \\
\text { under } 21 \text { years) in a car during } 11 \mathrm{pm} \text { and 5am\# }\end{array}$ & & & & & .50 \\
\hline Eigenvalues (before rotation) & 5.98 & 2.48 & 1.98 & 1.62 & 1.49 \\
\hline Explained variance after rotation (\%) & 27 & 11 & 9 & 7 & 6 \\
\hline
\end{tabular}


Note: Factor loadings $\geq .40$ are displayed. Bracketed loadings are unexpected cross loadings. 


\section{Table 2}

Means, Standard Deviations, and Cronbach's Reliability Coefficients of Scales

\begin{tabular}{lrrrr}
\hline Variable & $\begin{array}{r}\text { No. of } \\
\text { items }\end{array}$ & M & SD & $\begin{array}{r}\text { Cronbach } \\
\text { alpha }\end{array}$ \\
\hline Compliance with new rules* & 5 & 3.67 & .67 & .66 \\
Compliance with entrenched rules* & 4 & 4.93 & .15 & .57 \\
Formal deterrence** & 4 & 3.26 & .83 & .78 \\
Informal deterrence** & 4 & 3.00 & 1.12 & .87 \\
Shame-related emotion** & 5 & 4.11 & .86 & .89 \\
\hline
\end{tabular}

Note:

* Scale measured on a 1 (never) to 5 (always) scale.

** Scale measured on a 1 (strongly disagree) to 5 (strongly agree) scale 


\section{Table 3}

Hierarchical multiple regression model for the effect of deterrence scales on shame-related emotion.

\begin{tabular}{|c|c|c|c|c|c|c|}
\hline \multirow[b]{2}{*}{ Variable } & \multicolumn{3}{|c|}{ Model 1} & \multicolumn{3}{|c|}{ Model 2} \\
\hline & $\mathrm{B}$ & Std. Err. & $\beta$ & $\mathrm{B}$ & Std. Err. & $\bar{\beta}$ \\
\hline \multicolumn{7}{|l|}{ Step 1} \\
\hline Gender & .61 & .19 & $.27 * * *$ & .47 & .17 & $.21 * *$ \\
\hline Licence type & -.05 & .19 & -.03 & -.01 & .17 & -.01 \\
\hline Age & .05 & .04 & .11 & .06 & .03 & .13 \\
\hline Months of licensure & -.01 & .01 & -.17 & -.01 & .01 & -.13 \\
\hline \multicolumn{7}{|l|}{ Step 2} \\
\hline $\begin{array}{l}\text { Formal deterrence } \\
\text { (police }\end{array}$ & & & & .25 & .09 & $.24 * *$ \\
\hline $\begin{array}{l}\text { Informal deterrence } \\
\text { (parents) }\end{array}$ & & & & .20 & .06 & $.27 * *$ \\
\hline$R^{2}$ & & & $.11^{* *}$ & & & $.28 * * *$ \\
\hline Adjusted $R^{2}$ & & & .08 & & & .25 \\
\hline$R^{2}$ change & & & .11 & & & .17 \\
\hline$F$ change & & & $3.99 * *$ & & & $15.56 * * *$ \\
\hline $\mathrm{df}$ & & & $4(131)$ & & & $6(129)$ \\
\hline
\end{tabular}


Table 4

Hierarchical multiple regression model for the effect of deterrence on compliance with new rules, mediating for shame-related emotion

\begin{tabular}{|c|c|c|c|c|c|c|c|c|c|}
\hline \multirow[b]{2}{*}{ Variable } & \multicolumn{3}{|c|}{ Model 1} & \multicolumn{3}{|c|}{ Model 2} & \multicolumn{3}{|c|}{ Model 3} \\
\hline & B & $\begin{array}{l}\text { Std. } \\
\text { Err. }\end{array}$ & $\beta$ & B & $\begin{array}{l}\text { Std. } \\
\text { Err. }\end{array}$ & $\beta$ & B & $\begin{array}{l}\text { Std. } \\
\text { Err. }\end{array}$ & $\beta$ \\
\hline \multicolumn{10}{|l|}{ Step 1} \\
\hline Gender & .30 & .14 & $.17 *$ & .23 & .14 & .13 & .13 & .14 & .08 \\
\hline Licence type & -.29 & .15 & $-.22 *$ & -.27 & .14 & -.20 & -.27 & .14 & -.20 \\
\hline Age & .02 & .03 & .06 & .03 & .03 & .07 & .01 & .03 & .04 \\
\hline $\begin{array}{l}\text { Months of } \\
\text { licensure }\end{array}$ & -.01 & .01 & -.15 & -.01 & .01 & -.13 & -.01 & .01 & -.10 \\
\hline \multicolumn{10}{|l|}{ Step 2} \\
\hline $\begin{array}{l}\text { Formal } \\
\text { deterrence }\end{array}$ & & & & .07 & .07 & .09 & .03 & .07 & .03 \\
\hline $\begin{array}{l}\text { Informal } \\
\text { deterrence }\end{array}$ & & & & .13 & .05 & $.22 * *$ & .10 & .05 & .16 \\
\hline \multicolumn{10}{|l|}{ Step 3} \\
\hline $\begin{array}{l}\text { Shame-related } \\
\text { emotion }\end{array}$ & & & & & & & .19 & .07 & $.24 * *$ \\
\hline$R^{2}$ & & & $.13^{* * *}$ & & & $.20 * * *$ & & & $.24 * * *$ \\
\hline Adjusted $R^{2}$ & & & .10 & & & .16 & & & .20 \\
\hline$R^{2}$ change & & & .13 & & & .07 & & & .04 \\
\hline$F$ change & & & $67 * * *$ & & & $5.82 * *$ & & & $7.23 * *$ \\
\hline df & & & $4(131)$ & & & 6 (129) & & & 7 (128) \\
\hline
\end{tabular}


Table 5

Hierarchical multiple regression model for the effect of deterrence on compliance with entrenched rules, mediating for shame-related emotion

\begin{tabular}{|c|c|c|c|c|c|c|c|c|c|}
\hline \multirow[b]{2}{*}{ Variable } & \multicolumn{3}{|c|}{ Model 1} & \multicolumn{3}{|c|}{ Model 2} & \multicolumn{3}{|c|}{ Model 3} \\
\hline & B & $\begin{array}{l}\text { Std. } \\
\text { Err. }\end{array}$ & $\beta$ & B & $\begin{array}{l}\text { Std. } \\
\text { Err. }\end{array}$ & $\beta$ & B & $\begin{array}{l}\text { Std. } \\
\text { Err. }\end{array}$ & $\beta$ \\
\hline \multicolumn{10}{|l|}{ Step 1} \\
\hline Gender & .02 & .04 & .06 & .01 & .04 & .03 & -.02 & .04 & -.04 \\
\hline Licence type & .03 & .04 & .09 & .03 & .04 & .10 & .03 & .04 & .10 \\
\hline Age & .06 & .01 & .08 & .01 & .01 & .08 & .00 & .01 & .04 \\
\hline $\begin{array}{l}\text { Months of } \\
\text { licensure }\end{array}$ & -.00 & .00 & -.05 & .00 & .00 & -.03 & .00 & .00 & .01 \\
\hline \multicolumn{10}{|l|}{ Step 2} \\
\hline $\begin{array}{l}\text { Formal } \\
\text { deterrence }\end{array}$ & & & & .02 & .02 & .13 & .01 & .02 & .06 \\
\hline $\begin{array}{l}\text { Informal } \\
\text { deterrence }\end{array}$ & & & & .01 & .01 & .08 & -.00 & .01 & -.00 \\
\hline \multicolumn{10}{|l|}{ Step 3} \\
\hline $\begin{array}{l}\text { Shame-related } \\
\text { emotion }\end{array}$ & & & & & & & .06 & .02 & $.31 * *$ \\
\hline$R^{2}$ & & & .02 & & & .05 & & & $.12 *$ \\
\hline Adjusted $R^{2}$ & & & -.01 & & & .00 & & & .07 \\
\hline$R^{2}$ change & & & .02 & & & .03 & & & .07 \\
\hline$F$ change & & & .53 & & & 2.04 & & & $10.02 * *$ \\
\hline df & & & $4(129)$ & & & (127) & & & 7 (126) \\
\hline
\end{tabular}

Note: ${ }^{*} p<.05 ; * * p<.01 ; * * * p<.001$. 